\title{
Metaphors of Modernity: Palimpsestic Identities, Polygamous Marriages and Global Capitalism in Aidoo's Changes: A Love Story
}

\author{
Meyre Ivone Santana Da Silva
}

\begin{abstract}
Author:
Meyre Ivone Santana Da Silva

University of Oregon, USA

meyresantana94@gmail.com

https://orcid.org/0000-0001-8695-9535

Date of reception: 19/02/2021

Date of acceptance: 20/09/2021

Citation:

Santana Da Silva, Meyre Ivone. 2022. "Metaphors of Modernity: Palimpsestic Identities, Polygamous Marriages and Global Capitalism in Aidoo's

Changes: A Love Story." Alicante Journal of English

Studies 36: 131-147.

https://doi.org/10.14198/raei.2022.36.07

(C) 2022 Meyre Ivone Santana Da Silva

Licence: This work is licensed under a Creative Commons Attribution 4.0 International License (CC BY 4.0)

(c) (i)
\end{abstract}

\begin{abstract}
:
African routes to modernities have been marked by internal fissures and ambivalences that affect social life and political and economic structures in several ways. In the novel Changes: A Love Story, the Ghanaian writer Ama Ata Aidoo deals with the inconsistencies of modernities, asking whether global capitalism promotes gender equity or mainly contributes to social stratification, generating more complex hierarchies. This essay examines how Aidoo's narrative utilizes women's sexuality as an allegory to provide a vehement critique of colonial and post-independence policies, abusive indigenous practices, male privilege and corruption while shedding some light on women's condition in modern urban Accra.
\end{abstract}

Keywords: Aidoo, Ghana, Women, Literature, Modernity 


\section{Introduction}

David Harvey, in The Condition of Postmodernity, asserts that "modernity is characterized by a never-ending process of internal ruptures and fragmentations within itself" (1989, 12). While modernity reconfigures, transforms or adjusts societies according to the parameters of global capitalism, it is also very committed to "recuperations, continuity, and repressions" (Harvey, 2). Paradoxically, then, modernity focuses on the spread of capitalism and global interconnection while also being concerned with cultural identity. If on one side, modernity perceives cultural identity as fragmented, multifaceted and palimpsestic, on the other, it foments a search for cultural essence or authenticity. This internal contradiction often contributes to the ambivalent discourses which promote democracy and development as an ideal but also generate more social disruptions and complex inequalities besides class stratification. For instance, in African nations, underdeveloped versions of capitalism generally intersect with cultural traditions and patriarchy in intriguing ways, giving shape to what Shmuel Eisenstadt denominates multiple modernities, in other words, "a story of continual constitution and reconstitution of a multiplicity of cultural programs" $(2000,2)$. This essay draws on modernity as an unstable idea which inscribes different realities within diverse geographical, historical and cultural contexts. Here, I examine how Ama Ata Aidoo's novel, Changes: A Love Story, utilizes irony and sarcasm to provide us with a narrative that reveals the contradictions of Ghanaian modernity and the ways in which the conditions of women have been affected byit. .

In Aidoo's Changes, while male characters take advantage of modernity to achieve personal and social recognition through the tools provided by capitalism and development, they also exhibit a certain degree of fear because modernity challenges hegemonic masculinity and male power. Consequently, Men defend an idea of identity which is often connected to essentialism, through the maintenance of cultural traditions, religious dogma and patriarchal rules. Conversely, for the women in the novel, global capitalism and modernity are mainly connected to freedom, liberation, social mobility and the challenging of specific cultural traditions which often reinforce gender inequities. For April Gordon, capitalism and patriarchy are always interrelated in African contexts. She asserts that, "social forces that defend African patriarchy [...] will certainly continue to oppose many changes that favor women at the expense of male dominance - even if male dominance undermines economic development and capitalism" $(1996,10)$. In this sense, Aidoo's novel discusses the notion that the continued interest in maintaining hierarchies, through nationalist ideologies and 
religious or cultural traditions, creates a modern society which deprives women of freedom to participate fully in the process of development.

Aidoo's narrative represents modern urban Accra as an environment where apparently naïve love stories, quotidian affairs or private relationships reveal intrinsic contradictions that always mimic socio-political structures, ingrained corruption and the shortcomings of a postcolonial society. Through the use of irony and sarcasm, the narrator reveals that by attempting to be modern, men and women in urban Accra perform ambiguous and incoherent roles which promote and reinforce the very structures they allegedly abhor. As Claire Tylee asserts; "Irony is the major means by which subordinated and disaffected groups can implicitly refuse to concur with 'official culture' - and still manage to get published" $(2007,521)$. Aidoo confronts discourses of modernity, playing with the reader's expectations about life and love in urban Ghana. The protagonist's name, Esi Sekyi, might be a reference to the Ghanaian author Kobina Sekyi who wrote the celebrated satirical play The Blinkards, performed in Ghana in 1915 and 1917. Sekyi has been perceived as "a critical voice in the African modernist tradition" (Allan 2007, 430). In his play, he satirizes Europeanized Ghanaian characters who become alienated in their own country and incapable of understanding cultural norms. In Changes, the narrator plays tricks on Esi, satirizing her belief that a woman can take advantage of a polygamous relationship to have more freedom and personal fulfillment.

In Changes, Esi Sekyi, a professional, independent and successful statistician, divorces her husband and becomes the second wife of Ali, a charming, wealthy Muslim businessman. By attempting to profit from polygamy to have more freedom and happiness, Esi also goes through a process of metaphorical deafness and blindness which leads her to alienation. By claiming to be a feminist, Esi contradictorily becomes highly individualistic, selfish and cruel, as Nana WilsonTagoe argues, a "devourer of people, someone who commits emotional violence" (2004, 296). In Esi's feminist and capitalist world, there is no space for solidarity between women, which should be one of the main principles of her feminism. As capitalism and modernity assume new nuances in urban Accra, and class divides become more confusing, Esi's feminism gradually gets displaced, while Aidoo reminds the reader how her protagonist carries the legacy of the celebrated Ghanaian playwright Kobina Sekyi.

\section{Modernity and Conflicting Desires: Oko's Masculinity v. Esi's Liberation}

Aidoo's narrative reveals the ambivalences of modernity in Ghana through the lives of the men and women who facilitate capitalism and development, while at the same time as thwarting it. Shmuel Eisenstadt argues that the processes 
of westernization and modernity are diverse. For him, Western societies do not transfer patterns of modernity to developing countries, the appropriation process happening through "the continuous selection, reinterpretation, and reformulation of $[\ldots]$ imported ideas" $(2000,15)$. This process of appropriating concepts, ideologies, and ideas of development restructures political models and ideologies with respect to cultural, national and religious patterns discloses the continuous tension that marks modernity as Eisenstadt puts it, the "tension between conceptions of themselves as part of the modern world and ambivalent attitudes toward modernity in general and toward the West in particular" (15). As such, transformations do not take place without the incorporation and digestion of modernityThey are digested and then incorporated, into new models, not always smooth or simple, but underdeveloped capitalism changes reality which have the complexity of a puzzle which needs to recreate or reinvent some pieces.

Oko flung the bed cloth away from him, sat up, pulled her down, and moved on her. Esi started to protest. But he went on doing what he had determined to do all morning. He squeezed her breast repeatedly, thrust his tongue into her mouth, forced her unwilling legs apart, entered her, plunging in and out of her, thrashing to the left, to the right, pounding and just pounding away. Then it was all over. (9)

After this episode, which comes to be known by both Oko and Esi as "that morning," Esi realizes that what happened between them was really marital rape.

In her office after the episode, Esi feels frustrated, and impotent, thus making up her mind that marital rape is a motive for breaking up her marriage. She attempts to imagine herself giving a conference in her countryon marital rape and male privilege, but concludes that the audience would not understand the subject of such a lecture. The audience would see it as a unimportant issuebecause there would be no word in her native language for concept of marital rape.

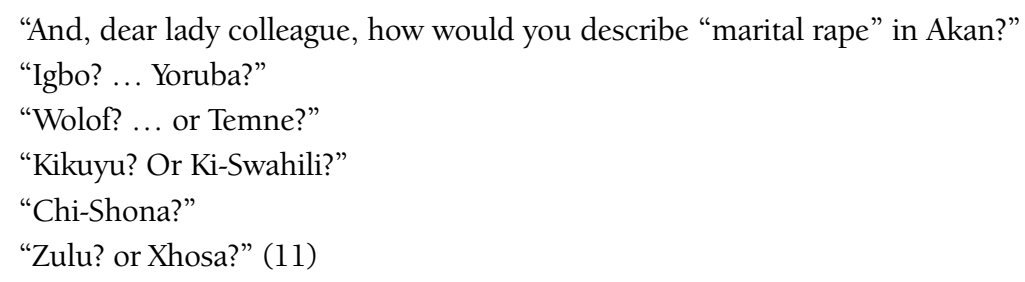

Esi concludes that since the term marital rape cannot be translated into her native language, discussion of this topic would probably not make any sense for women there. An experience that cannot be expressed in her native language would not be 
considered to have any relevance in that context. Though Aidoo's protagonist is a privileged and highly educated Ghanaian woman, the novel also deals with the situation of women excluded from colonial education; those who had minimal or no access to formal education become voiceless and disempowered. When English becomes the national and official language, part of the population is excluded from the decision-making process, and women generally have less opportunity to receive formal education. The novel's satirical tone highlights the protagonist's attempt to communicate through a language that other women cannot understand.

Juliana Makuchi Nfah-Abbenyi claims that though there is not a specific term in any Akan language for marital rape, by referring to the episode as "that morning," both Esi and Oko agree that something unusual happened between them. Oko's violence against Esi is real, and, though without naming it in her native language, "her experience is inferred, is named in codes that are available in a heteroglossia that is culturally specific, culturally translatable to both Esi and Oko" (292). Nfah-Abbenyi, who is from Cameroon, explains that though in her language, Bemba, there is no specific word for rape, there is an expression that means "a girl/woman has been spoilt. Thus, people who share the same culture will understand that a woman was raped" $(1999,291)$.

As Esi does not accept the husband's abusive relationship, Oko starts to see her as a betrayer of her culture. He asks himself: "But, what is an African woman?" (8). In his mind, being an African woman is about nurturing the family and attempting to please the husband. He cannot understand how Esi could reject him, a faithful, devoted, monogamous husband. Considering that most men are generally involved in polygamous relationships or have extramarital affairs, Oko seems to be one of the best men around. By depriving Esi of what he calls "Africaness", the husband utilizes culture as a way to safeguard his privileges. As he demands an African culture that is essentialist and specific, he decides that his wife cannot be a legitimate African woman if she does not perform according to his cultural expectations. If Oko understands that modernity deprives Esi of her culture, he also thinks that it threatens his masculinity. By trying to reaffirm his own masculinity, Oko searches within his culture for the parameters to control his wife by encapsulating her in the generalizing and essentialist category of "African woman."

A liberated and fulfilled woman, Esi appears to renounce her African identity because of the inherent sexism of many traditional African societies. Or if she "wishes to cherish and affirm her 'Africanness' she must renounce her claims to feminine independence and self-determination. Either way, she stands to lose; either way, she finds herself diminished" (Umeh 1986, 175). By disregarding an identity that is linked to unconditional obedience to patriarchal rules, Esi becomes a traitor to her culture. Though modernity is so concerned with restoring cultural 
values and identity, modern discourses do not deconstruct the fallacy of an integral identity. For instance, nationalist discourses created a mythical "African woman" who is always ready to sacrifice herself for the sons of her nation. Ama Ata Aidoo has argued that in the works of male writers, such as Chinua Achebe and Leopold Senghor, "African women were virtually silent observers who simply fulfilled their destiny without questioning it or the structures that sanctioned the roles they were made to assume" (Nfah-Abbenyi 2004, 5). Women's identities were connected to their role as mothers, quasi-spiritual beings who would take care of national heroes. Desire or sexual pleasure was not to be part of the life of this mythical spiritual entity who assumed the role of the mother.

The rape episode becomes an instrument of Oko's power, as well as of Esi's dehumanization. As the husband aims to reinforce his masculinity, he also wants to restore what he calls "African" femininity. In this context, Esi becomes trapped in a world where patriarchal rules assert that "what a woman wants is to be desired by her husband and defined exclusively in relation to that desire" (Olaussen 2002, 6). While Esi attempts to reconcile with the ambivalence that maintains her identity, Oko remains connected to the fantasy of a stable and indissoluble cultural identity. When he asks whether or not Esi is really an African woman, he is also trying to make sure that he continues to be an African man. In this sense, another question resonates in his mind: what is an African man? Oko is a desperate man who wants to maintain his status through the control of his educated wife whom he sees "as an adjunct to his ego, a crutch to bolster his image in the eyes of his co-workers and himself" (Odamtten 1994, 16). The only way he can find to let her know that he is still a man is through violence and objectification.

Catherine MacKinnon suggests that; "If what is sexual about a woman is what the male point of view requires for excitement, for arousal and satisfaction, have male requirements so usurped its terms as to have become them?" (1989, 118). However, when Esi gets the divorce, alleging that she was raped, she tries to resist objectification, contradicting her husband's logic that being a woman means satisfying his needs. By being considered an empty vessel, an object of her husband's sexual desire, Esi's own sexual desires have not been taken into consideration. She is expected to follow the patriarchal rules and be fulfilled simply by arousing male desire. The absence of female desire is expected during sexual intercourse, As Luce Irigaray has explained, patriarchy expects women to feel pleasure through their roles of satisfying men, hence women who want to have sexual pleasure do not know how to perform female roles in a patriarchal society:

How can this object of transaction claim a right to pleasure without removing her/itself from established commerce? With respect to other merchandise in 
the marketplace, how could this commodity maintain a relationship other than one of aggressive jealousy? How could material substance enjoy her/ itself without provoking the consumer's anxiety over the disappearance of his nurturing ground? How could that exchange - which can in no way be defined in terms "proper" to woman's desire - appear as anything but a pure mirage, mere foolishness, all too readily obscured by a more sensible discourse and by a system of more tangible values? (32)

Irigaray explains that if a woman is considered property and an object, she has no possibility of demanding anything, thus her sexual pleasure and desire are considered unimportant. When Esi claims her right to refuse her husband's desire, she destabilizes him, erasing his identity and forcing him to rethink his positionality. In order to deconstruct her identity and reestablish her desire, Esi must confront society and reevaluate herself. The situation becomes further complicated when Esi decides to get a divorce to be the second wife of a polygamous man.

Though Aidoo's protagonist focuses on women's rights and male abuse, the novel comes to terms with feminism and feminist language as a theory that cannot be transposed into Ghana without considering the perspectives of Ghanaian women. In Pedagogies of Crossing (2008), M. Jacqui Alexander remarks that the idea of a Global Feminism, a transnational feminism, or the feminism of the majority, often blurs categories of race, culture, and sexuality. Alexander warns of the dangers of subsuming the local into the global through applying the Western experience to the rest of the world. Her work aligns with that of Chandra Mohanty in advising Westerners on how to conduct their practices from the perspective that local and global interests might both converge and diverge, since categories of race, class, gender, and sexuality are differently nuanced in different locations.

Uma Narayan argues that Third World feminisms have nothing to do with importing ideas from the developed world and transplanting them into other cultural contexts. Hence Third World feminism "is not a mindless mimicking of 'Western agendas' in one clear and simple sense - that, for instance, Indian feminism is clearly a response to issues specifically confronting Indian women" $(1997,13)$. Narayan points out that women in Third World countries realize the necessity to forge new ways of conceptualizing feminisms which are coherent with their lives.

Here is an example of how women utilize creative language to reinvent feminist theories. he Cameroonian writer Werewere Liking created the term, "the misovire", a French neologism that means a male hater. For D'Almeida, Liking's invention is "all the more important as the creation of the word also creates the function, and the possibility of another reality" $(1994,20)$. The term coined by Liking has generated quite a few interesting debates for writers who struggle to 
come to terms with the intersection of categories, such as, class, race, nationality, religion, sex, and others. It is worth noting, as D'Almeida suggests, that the invention of misvoire does not mean "a gratuitous act; it's done for a redressive purpose, for besides filling a linguistic void, the word aims to destabilize the status quo, and it shows the extent to which social reality and literary expression are inextricably intertwined" $(1994,21)$.

Obioma Nnaemeka argues that the concept of African feminism probably does not do justice to the heterogeneity of Africa as a continent, with its numerous ethnic groups, languages and cultures. For Nnaemeka, Africa's pluralism must be respected and she argues that "to speak of feminism in Africa is to speak of feminisms in the plural within Africa and other continents in recognition of the multiplicity of perspectives" $(1998,31)$. Despite recognizing African heterogeneity and the complexities of a diverse continent, Nnaemeka envisions herself as part of a common struggle that has its foundation in pan-African ideals. In so doing, she aligns herself with other literary critics, such as Irene Assiba D'Almeida, who have affirmed that in using the term, their intention is not one of "totalization, but of a Pan-African perspective" (D'Almeida 1994, 23).

\section{Polygamous Marriages, Modernity and Women's Desire}

The polygamous relationship becomes the perfect site for Esi to combine all her aspirations. Every time Ali comes to her house, Esi is sure that she has taken the right decision. She is happy in a way she never felt before. The quality of life that Esi has with Ali gives her the security to accept his proposal of marriage, to become his second wife. Though she will be involved in a polygamous relationship, she is not the victimized wife who suffers because the husband is always not at home. On the contrary, in the beginning, she feels fulfilled.. She finally has a perfect relationship where she can be herself and does not have to deal with a man who interferes with her life all the time. Ali is the perfect match for an independent woman with an established career and in her relationship with him she attempts to combine "gender equality with sexual desire" (McWilliams 1999, 348).

Molara Ogundipe-Leslie (1994), however, affirms that though some women defend the polygamous system by arguing that in traditional cultures a woman can benefit from polygamy as she will have co-wives to help with the household work, she firmly believes that there is no justification to maintaining polygamy in postcolonial Africa, especially in the cities. She considers the system oppressive and suggests that those women who accept it might be contributing to their own victimization. In some novels, the theme has been overwhelmingly discussed, often not focusing on the positive aspects of polygamy, but on women's suffering when they are forced to accept the institution. 
Esi imagines that a polygamous marriage can provide her with happiness. Esi wants to marry Ali and live out her freedom. She does not consider her best friend's advice about the need to meet Fusena, the first wife, and have her acquiesce to the marriage, although she pretends to agree: "I will ask Ali to let his wife meet me before we go to see my people, Esi said a little defiantly, a little fearfully" (97). Although Esi promises her friend that she will attempt to follow traditional practices regarding polygamy, she never really puts pressure on Ali to meet his first wife. Nfah-Abbenyi points out that Esi "conceives the marriage in very individualistic ways" $(1999,295)$. In this sense, her decision might be seen as individualistic rather than feminist since it does not consider other women, only herself. She accepts the marriage to achieve her sexual self-determination, but she does not consider it within any social, historical or cultural contexts.

Esi tries to talk to Ali about polygamy and what it means in the modern urban African context. She thinks that perhaps they are not performing the polygamous relationship according to traditional and cultural expectations. Ali defends polygamy as a part of his identity. He points out that the practice has always existed in Africa and that its repudiation is nothing more than the acceptance of the standard imposed by colonialism. In Ali's discourse, his maintenance of polygamy is, thus, a way to defy Westernization. For him, as African Muslims, men from his culture have always chosen to marry more than one wife and this should not be a cause for shame.

To the people who created the concepts, these are all crimes. Like homicide, rape, and arson. Why have we got so used to describing our cultural dynamics with the condemnatory tone of our masters' voices? We have got marriages in Africa, Esi. In Muslim Africa. In non-Muslim Africa. And in our marriages a man has a choice - to have one or more wives." He paused dramatically, and then ended with a flourish: "As long as he can look after them properly". (90)

Ali's position regarding polygamy, however, reveals his incoherence as he advocates the adherence to traditional institutions as a form of reinforcing his identity, while at the same time deforming traditions to further his own interestsParadoxically perhaps, the tradition in Ghanaian culture demands a man to consult his first wife before choosing another woman to marry. Here, cultural contradictions mirror the ambivalence of modernity, which often sees culture as "essentialization and substantialization" (Friedman1995, 88).

Cultural traditions are often utilized to promote anti-imperialist and -colonialist discourses. For instance, the practice of genital mutilation was widely advocated by the revolutionary movement Mau Mau as a form of resistance to the impositions of the Catholic Church (Levin 1986, 209). As Chantal Zabus 
has pointed out, Jomo Kenyatta's Facing Mount Kenya "considered irua, the Kikuyu rite of both male circumcision and female excision in pubescent boys and girls as a source of cultural and ethnic identity and a form of resistance against missionary societies in East Africa. [...] Very quickly it appears that, more so than male circumcision, female excision [...] is linked with the survival of an ethnic group." $(2007,38)$. She/He asserts that one reason for this is that "Kenyatta considered irua as undissociated from the group's social cohesiveness. The marked Kikuyu body is a sociocultural artefact" (44). During the nationalist revolutionary struggles in Kenya, Jomo Kenyatta, the country's first president, asserted that if the Kikuyu were proud of their traditions, men should not marry non-circumcised women and in line with this, his first act as Head of State was to restore the practice of female circumcision in the country. Mau Mau embraced female circumcision as a traditional value and part of a dismantled culture that had to be restored (Levin 1986, 209-210). Elisabeth Bekers, in her article entitled "Empathizers" states that the body of creative writing, which includes fiction, poetry and drama, in many languages, and by men and women artists, dealing with the theme of female circumcision reflects how the practice has been supported by diverse ethnic groups across the continent (1999 15). Beckers also points out that in Charity Waciuma's Daughter of Mumbi, the narrator utilizes the discussion over genital mutilation "to construct an anti-imperialist plea for people's right to self-determination" (1999, 19). Ngug wa Thiong'o's The River Between presents genital mutilation/female circumcision as a problematic issue in Kenya although he does not undermine or openly criticize the practice. Conversely, some female writers such as Nawal El Sadawi clearly dismiss the practice as a repressive and patriarchal means of controlling women's bodies. In her work The Circling Song, the protagonist, an excised girl, resembles a prisoner surrounded by cement walls and with a rigid body.

Elleke Boehmer emphasizes the ways in which nationalist politics in Africa excluded the discussion about gender hierarchies and the need for female participation in the spheres of power. Nationalist discourses such as Negritude have often portrayed Africa as the motherland. In this sense, African women, Third World women and women of color need to overcome, Boehmer states, the triple oppression or marginalization that the effects of colonialism, gender and a male-dominated language create, often usefully adopted from the older and more established nationalist politics of "their men" (5).

Ali, the polygamous husband, often applies nationalist and cultural identity discourses to persuade Esi to accept his personal interpretation of polygamy. At the start of their relationship Esi tries to convince him that it is not prescribed in traditional culture to give an engagement ring to the second wife. He is breaking the rules. Ali convinces her that the tradition to which she is referring is recent 
because in Egypt husbands used to give rings to second and third wives. In the end, Ali says that a ring is a symbol that tells the world that Esi has become "occupied territory" (91). By utilizing patriarchal and colonial discourse which equates women's body to a territory, Ali appropriates Esi's body. Metaphors of colonized land as a virgin woman have been part of colonial discourses around the globe. Compared to a woman dispossessed of sexual desire and agency, the colonized land becomes embedded in patriarchal tales of male sexual fantasy. The land also turns into a site for the male colonizer's most perverted desires. As McClintock affirms, women become "the earth to be discovered, entered, named, inseminated, and above all, owned" (1985, 31).

For Ali, as soon as they are married, Esi becomes his property. Esi understands that Ali's power comes from a patriarchal society that benefits him and that he takes advantage of it; she accepts the deal and wears the ring. As he cannot spend enough time with her, the polygamous husband will occupy his land with cars, jewelry, art pieces, and other luxury items. With his money, he will be able to maintain his "territory" while he is away taking care of his first wife and children. In the meantime, Esi struggles with this new situation and fights to resist victimization, recalling that her mother and grandmother had advised that polygamy can be oppressive for women and that second and third wives may experience pain and suffering.

Esi ignored her mother's and grandmother's advice about the status of second wives in a polygamous marriage and married Ali because she is certain that this is the ideal relationship for a woman in her position. However, she starts to think carefully about all the advice she didn't listen to when she realizes that Ali already has a home, and, as a husband and father, has duties there. In addition, he has to perform rituals with his children, especially during the holidays when he has to stay home, give gifts to them and have dinner with them. At these moments, Esi is alone in her house, taking pills to sleep, and trying to cope with the consequences of her choices. And it is during these nights of loneliness in her bedroom that Esi remembers her mother's and grandmother's advice.

Lying alone in bed with her eyes hard and wide-open in the dark, she remembers some of the advice her mother and her grandmother had given her. They told her to be careful and that being one of any number of wives has its rules. If she obeyed the rules, a woman like her should be all right. If she broke the rules, then her new marriage would be like a fire that had been lighted inside her. They recited some of the rules to her. They made her aware of some pitfalls. Above all, they said, there were two things she had to bear in mind at all times. One was never to forget that she was number two, and the other was never to show jealousy. (116) 
After the honeymoon period is over, Esi finds herself trapped in her marriage. Ali starts to set the rules, stops calling or coming to the house, and substitutes his presence with tons of gifts on her doorstep. Esi starts to feel like the other woman in an adulterous relationship. Her marriage is a distortion of the institution of polygamy in which there are no rules that the husband has to follow. In polygamous marriages, the husband should give equal attention to all the wives, but Ali simply disappears for days, weeks, or even months. As Ali has made Esi a territory, his property, he decides what to do with her. Ali is living a polygamous life that is very convenient for him.

Later, Ali finds a new lover and his absences become longer. Esi finds herself lonely, frustrated and sex-starved. In one of these moments, Kubi, Opokuya's husband comes to the house and reveals the desire he has kept in secret for so long. When Oko reveals that he wants to have sex with Esi, she lets him know that she is ready.

No words came. Kubi took hold of her hand maybe to lead her into the room and get her to sit down. He found himself holding her close. Then, as though he had taken a quick decision just in that minute, turned to face her and hold her closer and hard. She did not feel like offering resistance. He began to kiss her face, her neck and all over. Then they were moving towards the couch and Esi could feel Kubi's manhood rising. (163)

Esi stops Kubi, though, when she remembers that he is her best friend's husband. Although she wants to spend the night with Kubi, it could mean suffering for Opokuya, a woman who needs to work hard to survive. While Esi earns a decent wage, lives in a nice house, and gets a brand new car as one of Ali's gifts, Opokuya quarrels with her husband about a car that she never has the opportunity to drive.

As an independent woman, Esi's main goal is to pursue her own pleasure through sexual fulfillment, personal achievement, and consumerism. Göran Therborn remarks that the establishment of capitalism foresees the combination of two major actions: one individualistic and the other associative. The individualist action deals with an individual's well-being, performance, education, choice which "are ... freedom/prosperity/happiness/development/welfare" (1995, 135). The associative action, on the other hand, sees "collectivity, unity, co-operation, solidarity, and organization as the best road to freedom, justice, strength, and development" (135). For Therborn, two social spheres of modernity - individualism, and association- occur mainly in the economy and the family. They can be carried out by economic agents and by parents and children, husband and wife. Although Esi has a preoccupation with women's rights, she reveals herself as an individualist who is not capable of uniting with other women to pursue a collective agenda. 
Nevertheless, class divisions also play a part in preventing Esi's feminist agenda, in line with April Gordon's assertion that "efforts to promote gender equity for women under a capitalist regime include minimizing class inequality" $(1996,10)$.

For instance, Opokuya's aspirations do not match with Esi's vision of freedom and liberation. Opokuya's sexual desire vanishes from the narrative, the absence giving space to another desire. Her freedom is based on her right to drive a car, to buy a car, and be free from the constraints of begging to use her husband's car-a car provided by the government. In Opokuya's life, sexual pleasure appears as a secondary preoccupation, a luxury for a woman who needs to get up at five in the morning every day to go to work. It is ironic that sexual desire is not among the aspirations of a woman who does not have money to buy her own car to get to work or to take her children to school. Esi's construction of subjectivity happens at the level of her freedom to divorce and have more space in a polygamous marriage; while Opokuya's is connected to her work and capacity to survive and raise her children. Opokuya's desires are fulfilled with an old car that Esi decides to give her as a gift. At the end of the narrative, Opokuya drives freely, laughs in her car, and enjoys pleasure for the first time.

\section{Fusena's Desire for Mobility}

For Fusena, Ali's first wife, Esi is a concubine, not a second wife. Ali is being an adulterous husband rather than a polygamous one. In a polygamous relationship, the first wife needs to give her permission for the husband to have a second wife. However, Ali decided to marry Esi without communicating with his first wife. Ali is abusing a system in order to fulfill his desires. As Ali claims to be an African man, he is also saying that his culture gives him a license to find other wives when he wants. At the beginning of the novel, Fusena and Ali's relationship is described as a strong friendship that gradually turns to love. Fusena desires more education. She would love to go to a college and get another degree, band become a professional woman with a career. When she chooses to marry Ali and accompanies him to Europe, she makes a silent deal to forget herself. Back in Ghana, Ali opens a small business for his wife. Fusena is there most of the time, taking care of the business to the point of being recognized as one of best traders in the city. Hence, Fusena always carries the secret fear that one day, Ali will find a woman with a college degree to be her co-wife, humiliating her.

When Ali becomes involved with Esi, Fusena becomes frustrated and bitter and tries to convince her husband that his relationship with Esi cannot be considered a marriage. He is committing adultery. When Ali makes up his mind to marry Esi, Fusena goes to the village to ask the elders for advice and help because what Ali is doing is against their religion, and this marriage should not be permitted. Though 
the elders listen to Fusena, they decide to help Ali marry his second wife.

Fusena's pain becomes increasingly visible as her voice starts to disappear. Fusena does not speak many complete sentences or enter into any of the discussions, instead, using short sentences and monosyllabic answers. When Ali comes home to give her the news about his second wife, she asks, "She has a university degree?" (98). That question is all she can ask before rushing to seek help from the elders. From this passage on, Fusena is silent. She stops speaking, and her silence is symbolic. As she starts to disappear, her pain becomes unimportant in a society that moves in so many contradictory directions. Consequently, Fusena's body and beauty become invisible. She appears unattractive and no longer inspires any sexuality or sensuality. Fusena's body gained importance as a commodity, a property, and existed to give birth to Ali's children. Interestingly, like Opokuya, Fusena finds freedom, fulfillment and pleasure in her car: "Before starting her car, which was a small two-door vehicle she had come to love unreasonably and fiercely, she removed her veil completely and put it together with the handbag on the passenger seat next to her. The car screeched into life" (99). As such, the car frees Fusena from religious and societal constraints, and alone, inside her car, she feels pleasure. It is also metaphoric that the car gives her back her "life", a life she finds in the confinement and solitude of a vehicle that gives her freedom to move.

Fusena and Esi happen to be part of the incoherence of urban Accra, where certain values are distorted or transformed to benefit patriarchy. On the one hand, Fusena represents tradition and religion and accepts a polygamous relationship that is unfair. Though she is a successful businesswoman, she does not divorce Ali or attempt to find happiness in other relationships. Esi, on the other hand, chooses a polygamous marriage in order to have more freedom and sexual satisfaction but is also victimized. Silently, Fusena and Esi compete for Ali, but what is implicit is how both women play a part in his life-Esi is for sex and Fusena is a housewife. Fusena is trapped in the stereotype of a self-sacrificing mother and housewife who lives for the family. Esi is the stereotyped individualist who attempts to fulfill her sexual needs through a polygamous marriage that ignores male privilege and gender roles in that context. Either way, Ali has the power to decide how he manages a polygamous relationship that provides him with the assertion of his "African" identity. While both women are competing for Ali, he gets a third woman, a new secretary who becomes his love affair.

\section{Conclusion}

In Changes, Ama Ata Aidoo's narrator shares with the reader the incongruences of modern life in an African urban city. The protagonist Esi Sekyi, a successful woman 
advocates feminism and women's rights to pursue freedom. Esi, though, is not able to see that her actions cause pain to another woman, Fusena, Ali's Muslim first wife. Fusena and Esi represent different fragments of a modern society where there are opposite and even antagonistic paths down which the two women try to find freedom and liberation. While Esi emerges as an individualist and capitalist who tries to achieve freedom through sexual pleasure, consumerism, luxury items and hedonism, Fusena frees herself from religious and cultural hierarchies inside her car, which becomes a metaphor for mobility and liberation. Fusena's womanhood diverges so much from Esi's that Esi's political consciousness and struggle for freedom become displaced in urban Accra.

Polygamy is bitter for Fusena and bittersweet for Esi; by the end of the novel, both of them understand the practice is not advantageous for women. Esi misunderstands polygamy and its rules and attempts to take advantage of the system, but in doing so, she contributes to another woman's victimization and her own unhappiness. She tries to achieve self-satisfaction with polygamy because of her economic status and education, but in the end, she understands that she has taken a dangerous path in pursuit of her personal freedom. Although it contributes to her ephemeral feeling of happiness and personal fulfillment, Esi Sekyi's feminism, which is highly motivated by individualism, in fact strengthens patriarchy and capitalism in a modern world where powerful men, such as Ali, take advantage of cultural values, religion, and capitalism, to maintain women as subalterns of modernity.

\section{Works Cited}

Alexander, M. Jacqui. 2008. Pedagogies of Crossing. Durham: Duke UP.

Allan, Tuziline Jita. 2007. "Modernism, Gender and Africa" In Scott 2007, 427-437

Aidoo, Ama Ata. 1991. Changes: A Love Story. London: Cox and Wyman.

Azodo, Ada Uzoamaka and Gay Alden Wilentz, eds. 1999. Emerging Perspectives on Ama Ata Aidoo. Trenton, NJ: Africa World Press.

BÂ, Mariama. So Long a Letter. Translated by Modupe Bode-Thomas, Oxford: Heinemann, 1989.

BEKERS, Elisabeth. 1999. "Empathizers" In Chantal Zabus. Changements au féminin en Afrique noire..L'Harmattan.

Boenmer, Elleke. "Stories of Women and Mothers: Gender and Nationalism in the Early Fiction of Flora Nwapa." In Nasta 1991, 3-23.

Boyce Davies, Carole and Anne Adams Graves, eds. 1986. Ngambika: Studies of Women in African Literature. Trenton, NJ: Africa World Press.

D'Almeida, Irene Assiba. 1994. Francophone African Women Writers: Destroying the

Emptiness of Silence. Gainesville: U of Florida P. 
Eisenstadt, S.N. 2000. “Multiple Modernities”. Dedalus, Vol 129, No. 1, 1-29

El SADAwI, Nawal. 1989. The Circling Song. London: Zed Books

Featherstone, Mike, Scott Lash and Roland Robertson, eds. 1995. Global Modernities.

London: Sage Publications.

GoRdon, April. 1996. Transforming Capitalism and Patriarchy: Gender and Development in Africa. Boulder: Lynne Rienner Publishers.

Harvey, David. 1989. The Condition of Postmodernity: An Enquiry into the Origins of Cultural Change. Oxford: Blackwell.

IrIGARAY, Luce. 1985. This Sex Which is Not One. Translated by Catherine Porter with Carolyn Burke. Ithaca, NY: Cornell UP.

Friedman, Jonathan. 1995. "Global System, Globalization and the Parameters of Modernity." In Featherstone, Lash and Robertson, 124-139

LesLiE, Molara Ogundipe. 1994. Recreating Ourselves. Treton: African Worl Press

LEvin, Tobe. "Women as Scapegoats of Culture and Cult: An Activist's View of Female

Circumcision in Ngũgĩ's The River Between." In Boyce Davies and Adams Graves 1986, ADD PAGES 208-17

Liking, Werewere. Elle sera de Jaspe et de Corail. Paris: L'Harmattan, 1983.

McClintock, Anne. 1995. Imperial Leather: Race, Gender and Sexuality in the Colonial Contest. New York: Routledge.

MacKinnon, Catherine. 1989. Toward a Feminist Theory of State. Cambridge: Harvard UP.

McWilliams, Sally. "Strange As It May Seem: African Feminisms in Two Novels by Ama Ata Aidoo." In Azodo and Alden Wilentz 1999, 333-361.

Ogundipe - LesLie, Molara. 1994. Recreating Ourselves. Treton: African Worl Press.

Narayan, Uma. 1997. Dislocating Cultures/ Identities, Traditions, and Third World Feminism. New York: Routledge.

NASTA, Susheila, ed. 1991. Motherlands: Black Women's Writings from Africa, the Caribbean and South Asia. London: Women's Press.

NASTA, Susheila, ed. 2004. Writing Across Worlds: Contemporary Writers Talk. London: Routledge.

Nfah-AbBEnyi, Juliana Makuchi. "Flabberwhelmed or Turning History on its Head? The Postcolonial Woman-as-Subject in Aidoo's Changes: A Love Story." In Azodo and Alden Wilentz 1999, 281-302.

Nnaemeka, Obioma, ed. 1998. Sisterhood, Feminisms and Power in Africa: From Africa to the Diaspora. Trenton, NJ: Africa World Press.

Odamtten, Vincent. 1994. The Art Of Ama Ata Aidoo: Polylectics and Reading Against Neocolonialism. Gainesville: U of Florida P.

Olaussen, Maria. 2002. "About Lovers in Accra- urban Intimacy in Ama Ata Aidoo's Changes: A Love Story." Research in African Literatures 33: 61-80. 
SEKYI, Kobina. 1997. The Blinkards, a Comey: And, the Aglo-Fanti, a Short Story. Accra: Readwide Publishers/Heinneman Educational.

Scott, Bonnie K., ed. 2007. Gender and Modernism. New Geographies. Complex Intersections. Urbana and Chicago: $\mathrm{U}$ of Illinois $\mathrm{P}$.

Tylee, Claire M. 2007. "War, Modernisms, and the Feminized Other." In Scott 2007, 519-528.

Therborn, Gorän. 1995. "Routes to/ Through Modernity". In Featherstone, Lash and Robertson, 1995, 124-139.

Umen, Marie Linton. 1986. "Reintegration With the Lost Self: A Study of Buchi Emecheta's Double Yoke.” In Boyce Davies and Adams Graves 1986, 173-180.

Zabus, Chantal. 2007. Between Rights and Rites: Excision in Women's Texts. Stanford University Press.

WA Thiong'o Ngugi. The River Between. Heineman. African Writer Series. Oxford: Oxford University Press.

Wilson-Tagoe, Nana. 2004. Interview with Ama Ata Aidoo. In Nasta 2004, 292-300. 